\title{
PENYUSUNAN MODUL DAN PELATIHAN PEMBELAJARAN KOOPERATIF UNTUK MGMP BAHASA INGGRIS SMP SUB RAYON 1 UNGARAN: PENGEMBANGAN KOMPETENSI SIKAP, PENGETAHUAN, DAN KETERAMPILAN PESERTA DIDIK
}

\author{
Puji Astuti, Prayudias Margawati, Anjar Pangestu \\ Fakultas Bahasa dan dan Seni, Universitas Negeri Semarang \\ Email: puji.astuti.ssu@mail.unnes.ac.id
}

\begin{abstract}
The problems faced by the English MGMP teachers of JHS Sub Rayon 1 Ungaran (partners) are that they need the following: 1) practical guidance in implementing the Curriculum 2013 (Kurtilas), especially in carrying out learning activities, 2) training of learning activities which integrate and develop the attitudes, knowledge, and skills of learners, and 3) training on learning activities that can help learners to improve communicative competence in English. Therefore, the purpose of community service activities is to improve the knowledge and skills of MGMP partner teachers in Kurtilas. More specifically, this activity aims to improve the knowledge and skills of teachers in the MGMP in applying cooperative learning. The teaching methods mandated by Kurtilas can develop the competence of students' attitudes, knowledge, and skills and enhance their communicative competence in English. This devotional activity also aims to make the experience of MGMP teachers increasing especially in viewing, applying, and giving feedback about the process of cooperative learning in learning English. To achieve these objectives, the devotional team carries out the following activities: 1) the preparation of cooperative learning modules, 2) cooperative learning training, and 3) assistance in applying cooperative learning in schools. All activities are well executed and trainees gain experience, knowledge, and skills on applying cooperative learning to the development of students' knowledge, skills, and attitude competencies. Keywords: cooperative learning, knowledge competence, skill competence, attitude competence.
\end{abstract}

Keyword: cooperative learning, knowledge competence, skill competence, attitude competence
Abstrak. Permasalahan yang dihadapi oleh guru-guru MGMP bahasa Inggris SMP Sub Rayon 1 Ungaran (mitra) adalah bahwa mereka membutuhkan hal-hal berikut: 1) panduan praktis dalam melaksanakan Kurikulum 2013 (Kurtilas), khususnya dalam melaksanakan kegiatan pembelajaran, 2) pelatihan kegiatan pembelajaran yang mengintegrasikan dan dapat mengembangkan sikap, pengetahuan, dan keterampilan peserta didik, dan 3) pelatihan tentang kegiatan pembelajaran yang dapat membantu peserta didik untuk meningkatkan kompetensi komunikatif dalam bahasa Inggris. Oleh karena itu, tujuan kegiatan pengabdian kepada masyarakat ini adalah meningkatkan pengetahuan dan keterampilan guru-guru MGMP mitra dalam Kurtilas. Lebih spesifik, kegiatan ini bertujuan meningkatkan pengetahuan dan keterampilan guru-guru dalam MGMP tersebut dalam menerapkan pembelajaran kooperatif. Metode pengajaran yang dimandatkan oleh Kurtilas ini 
dapat mengembangkan kompetensi sikap, pengetahuan, dan keterampilan peserta didik serta meningkatkan kompetensi komunikatif mereka dalam bahasa Inggris. Kegiatan pengabdian ini juga bertujuan agar pengalaman guru-guru MGMP mitra bertambah terutama dalam melihat, menerapkan, dan memberikan balikan tentang proses berjalannya pembelajaran kooperatif dalam pembelajaran bahasa Inggris. Untuk mencapai tujuan tersebut, tim pengabdi melaksanakan kegiatan-kegiatan berikut: 1) penyusunan modul pembelajaran kooperatif, 2) pelatihan pembelajaran kooperatif, dan 3) pendampingan penerapan pembelajaran kooperatif di sekolah. Semua kegiatan telah terlaksana dengan baik dan peserta pelatihan mendapatkan pengalaman, pengetahuan, dan ketrampilan tentang penerapan pembelajaran kooperatif untuk pengembangan kompetensi pengetahuan, ketrampilan, dan sikap peserta didik.

Kata Kunci: Pembelajaran kooperatif, kompetensi pengetahuan, kompetensi keterampilan, kompetensi sikap

\section{PENDAHULUAN}

Seperti diketahui bersama, Kurikulum 2013 (Kurtilas) pertama kali diluncurkan pada awal tahun ajaran 2013/2014. Setelah diujikan pada sekolahsekolah eks-Rintisan Sekolah Berstandar Internasional (RSBI) selama tiga semester, kurikulum tersebut kemudian direvisi pada semester genap tahun ajaran 2014/2015 dan hasilnya diluncurkan pada semester ganjil tahun akademik 2016/2017 yang lalu. Dalam payung Kurtilas, seperti halnya dalam kurikulumkurikulum sebelumnya, pengajaran bahasa Inggris di Indonesia (latar belakang akademik dan profesional tim pengabdi, biodata dapat di lihat di Lampiran 1) menggunakan pendekatan komunikatif. Sesuai namanya, pendekatan ini bertujuan untuk membantu pembelajar bahasa mencapai kompetensi komunikatif melalui interaksi mereka dengan rekan sejawat dengan menggunakan bahasa Inggris (Larsen-Freeman, 2012; Richard, 2002).

Perbincangan informal dengan beberapa guru bahasa Inggris di Ungaran selama ini serta kegiatan sharing dan diskusi dengan guru-guru di MGMP Bahasa Inggris SMP Sub Rayon I Ungaran pada tanggal 28 Februari 2017 (foto kegiatan ini dapat dilihat di Lampiran 2) memberikan tim pengabdi gambaran tentang tantangan pelaksanaan Kurtilas. Berikut ini beberapa detilnya.

Pertama, seperti temuan penelitianpenelitian yang telah dibahas di bagian sebelumnya, guru-guru bahasa Inggris di MGMP tersebut memerlukan panduan praktis tentang bagaimana menerapkan Kurtilas, terutama dalam melaksanakan kegiatan pembelajaran. Kedua, disebutkan dalam Standar Proses Pendidikan Dasar dan Menengah (Permendikbud nomor 22 tahun 2016) bahwa tiga ranah kompetensi-sikap, pengetahuan, dan keterampilan-harus menjadi tujuan setiap pembelajaran. Guru-guru di MGMP tersebut menyampaikan bahwa mereka memerlukan pelatihan kegiatan pembelajaran yang mengintegrasikan dan dapat mengembangkan tiga ranah kompetensi tersebut. Ketiga, mereka memerlukan pelatihan tentang kegiatan pembelajaran yang dapat membantu peserta didik untuk meningkatkan kompetensi komunikatif dalam bahasa Inggris.

Ketua tim pengabdi adalah seorang praktisi dan peneliti cooperative learning atau pembelajaran kooperatif (road map penelitian dan pengabdian ada di 
Lampiran 3) dan percaya bahwa metode pengajaran tersebut dapat membantu memecahkan permasalahan-permasalahan yang dihadapi oleh mitra. Berikut ini beberapa alasan dan penjelasannya.

Pertama, Standar Proses Pendidikan Dasar dan Menengah (Pemendikbud Nomor 22 Tahun 2016) untuk Kurtilas yang telah direvisi menyebutkan 14 prinsip pembelajaran. Ketua tim pengabdi melihat bahwa paling tidak dua diantara prinsip-prinsip tersebut dapat direalisasikan melalui pembelajaran kooperatif, yaitu: 1) dari peserta didik diberi tahu menuju peserta didik mencari tahu (prinsip nomor 1) dan 2) pembelajaran yang menerapkan prinsip bahwa siapa saja adalah guru, siapa saja adalah peserta didik, dan dimana saja adalah kelas (prinsip nomor 12). Di dalam pembelajaran kooperatif, kerjasama dan interaksi antar peserta didik terstruktur/berpola. Hal ini memungkinkan mereka untuk secara aktif mencari tahu dan menjadikan teman sejawatnya sebagai sumber belajar dalam proses membangun pemahaman mereka tentang materi pembelajaran.

Masih di dalam Standar Proses, tepatnya di panduan penyusunaan Rencana Pelaksanaan Pembelajaran (RPP), juga disebutkan bahwa guru perlu menyelenggarakan pembelajaran yang mendorong partisipasi aktif peserta didik serta pembelajaran yang berpusat pada peserta didik. Tinjauan pustaka yang dilakukan ketua tim pengabdi menunjukkan bahwa pembelajaran kooperatif dapat membantu guru untuk merealisasikan konsep-konsep tersebut (Cohen, 1994; Keyser, 2000; Richards, 2002; Sharan, 2002).

Kedua, telah banyak sekali penelitian yang menunjukkan bahwa pembelajaran kooperatif dapat membantu guru untuk mengembangkan kompetensi sikap, pengetahuan, dan keterampilan peserta didik. Berikut ini beberapa contohnya: pembelajaran kooperatif untuk meningkatan kepercayaan diri siswa (Coelho, 2009; Johnson \& Johnson, 1999; Kagan \& Kagan, 2009, Slavin, 1990), kecintaan siswa pada sekolah dan kelasnya (Kagan \& Kagan, 2009; Slavin, 1990), pada pertemanan dengan rekan sejawatnya (Johnson \& Johnson, 1999; Slavin, 1990), relasi antar ras/suku dalam kelas (Kagan \& Kagan, 2009; Slavin, 1980), dan untuk meningkatkan keterampilan sosial (Johnson \& Johnson, 2009; Kagan \& Kagan, 2009; Slavin, 1990).

Di wilayah pengembangan kompetensi pengetahuan, khususnya dalam pembelajaran bahasa Inggris sebagai bahasa asing dan bahasa kedua, pembelajaran kooperatif terbukti dapat meningkatkan penguasaan pembelajaran bahasa pada komponen-komponen bahasa, seperti tata bahasa (Bejarano, 1987; Hijazi \& Al-Natour, 2012), kosakata (Bejarano, 1987), and pelafalan (Chen, 2011). Selanjutnya, pembelajaran kooperatif juga dapat meningkatkan keterampilan mendengarkan (Bejarano, 1987), keterampilan berbicara (Liang, 2002; Sachs, Candlin \& Rose, 2003), membaca (Bejarano, 1987; Ghaith, 2003), dan keterampilan menulis (Syafini \& Rizan, 2009).

Ketiga, pembelajaran kooperatif berada di bawah payung pendekatan komunikatif (Richards, 2002) karena metode pengajaran tersebut menekankan pada kerjasama/interaksi antar siswa dan penggunaan bahasa Inggris dalam interaksi tersebut (Larsen-Freeman, 2012; Richards, 2002). Oleh karena itu, jika diterapkan dengan konsisten, pembelajaran kooperatif dapat membantu peserta didik untuk mencapai kompetensi komunikatif dalam bahasa Inggris. Berdasarkan hal-hal tersebut di atas, tim pengabdi membantu memecahkan 
permasalahan-permasalah mitra dengan menggunakan pembelajaran kooperatif.

Berdasarkan permasalahan yang telah dirinci, masukan dari ketua MGMP Sub Rayon 1 Ungaran (M. Rustini, S.Pd./Guru bahasa Inggris SMPN 5 Ungaran), serta posisi dan manfaat pembelajaran kooperatif, maka tim pengabdi membantu menyelesaikannya dengan melaksanakan kegiatan-kegiatan di bawah ini:

a. Penyusunan modul sebagai panduan praktis bagi guru-gurubahasa Inggris dalam menerapkan Kurtilas, khususnya dalam menerapkan pembelajaran kooperatif dalam kegiatan pembelajarankooperatif. Melalui media sosialnya, semenjak empat tahun yang lalu ketua tim pengabdi mendeseminasikan selukbeluk pembelajaran kooperatif dalam bentuk gambar yang dibuat oleh ilustrator profesional (conto- contoh ada di Lampiran 4/Kegiatan Diseminasi Pembelajaran Kooperatif Melalui Media Sosial Ketua Tim Pengabdi). Langkah tersebut memberikan pengalaman tentang bagaimana membuat materi yang menarik untuk media belajar guru khususnya tentang pembelajaran kooperatif. Pada Lampiran 5 terdapat Cuplikan Isi Modul. Versi lengkapnya dibagikan kepada peserta pelatihan.

b. Pelatihan pembelajaran kooperatif untuk mengembangkan kompetensi sikap, pengetahuan, dan keterampilan peserta didik serta meningkatkan kompetensi komunikatif peserta didik dalam bahasa Inggris.

c. Pendampingan penerapan pembelajaran kooperatif di kelas bahasa Inggris guru-guru MGMP mitra di sekolah mereka.

d. Peer teaching/mengajar rekan sejawat dengan menggunakan teknik-teknik pembelajaran kooperatif.
Selaras dengan solusi yang telah dirinci pada bagian sebelumnya, tim pengabdi menargetkan hal-hal berikut untuk dicapai melalui pelaksanaan kegiatan pengabdian:

a. Peningkatan pengetahuan guru-guru MGMP bahasa Inggris SMP Sub Rayon 1 Ungaran (mitra) tentang Kurtilas, khususnya tentang pembelajaran kooperatif sebagai kegiatan pembelajaran aktif yang dimandatkan oleh kurikulum tersebut.

b. Peningkatan keterampilan guru-guru di MGMP mitra dalam menerapkan pembelajaran kooperatif, khususnya untuk mengembangkan kompetensi sikap, pengetahuan, dan keterampilan peserta didik serta meningkatkan kompetensi komunikatif mereka dalam bahasa Inggris.

c. Bertambahnya pengalaman guru-guru MGMP mitra dalam melihat, menerapkan, dan memberikan balikan tentang proses berjalannya pembelajaran kooperatif dalam pembelajaran bahasa Inggris.

\section{METODE}

Telah disinggung bahwa untuk menyelesaikan permasalahan mitra, tim pengabdi melaksanakan kegiatan pengabdian pada masyarakat, yang akan dibagi menjadi tiga sub kegiatan, yaitu: a) penyusunan modul pembelajaran kooperatif, b) pelatihan pembelajaran kooperatif, dan c) pendampingan penerapan pembelajaran kooperatif di sekolah.

Prosedur kerja kegiatan penyusunan modul pembelajaran kooperatif untuk guru-guru bahasa Inggris di MGMP mitra meliputi langkah-langkah berikut:

a. Memilih teknik-teknik pembelajaran kooperatif yang akan ditampilkan di modul. Pemilihan ini diperlukan karena berdasarkan dari ketua MGMP mitra, M. Rustini, S.Pd., guru-guru 
dalam MGMP-nya sudah mengenal beberapa teknik pembelajaran kooperatif dan menggunakannya dalam pengajaran mereka. Oleh karena itu, tim pengabdi akan memilih teknikteknik pembelajaran kooperatif yang jarang mereka gunakan atau belum mereka kenal sama sekali.

b. Memilih minimal empat Kompetensi Dasar (KD) yang tertulis di Standar Isi (Permendikbud nomor 21 tahun 2016) yang mencakup empat keterampilan berbahasa: menyimak, berbicara, membaca, dan menulis (listening, speaking, reading, dan writing) dan komponen-komponen bahasa. Berdasarkan masukan dari mitra, komponen bahasa yang akan menjadi fokus dalam kegiatan pengabdian pada masyarakat ini adalah tata bahasa (grammar) dan kosakata (vocabulary). Selanjutnya, berdasarkan beberapa KD tersebut, tim pengabdi akan menuliskan enam tujuan pembelajaran yang masing-masing kemudian akan dikembangkan menjadi skenario dan digandakan untuk kemudian dibagikan kepada guru-guru di MGMP mitra.

Untuk sub kegiatan pelatihan pembelajaran kooperatif, prosedur kerjanya meliputi langkah-langkah berikut

a. Berdasarkan draft modul pembelajaran kooperatif untuk mata pelajaran bahasa Inggris SMP yang telah disusun, tim pengabdi merancang kegiatan pelatihan.

b. Menyelenggarakan pertemuan pertama dengan fokus pada pembelajaran kooperatif untuk meningkatkan kompetensi pengetahuan peserta didik.

c. Menyelenggarakan pertemuan kedua dengan fokus pada pembelajaran kooperatif untuk meningkatkan kompetensi keterampilan peserta didik.

d. Menyelenggarakan pertemuan ketiga dengan fokus pada pembelajaran pembelajaran.

c. Menulis pembahasan tentang bagaimana melalui keenam pembelajaran tersebut, sikap, pengetahuan, dan keterampilan peserta didik terbangun. Pembahasan ini akan disertai kutipan dari penelitianpenelitian yang relevan.

d. Menulis pembahasan tentang bagaimana melalui keenam pembelajaran tersebut, keterampilan dan komponen bahasa yang menjadi target terbangun. Seperti pada bagian sebelumnya, pembahasan tentang pembelajaran kooperatif dan pengembangan keterampilan dan komponen bahasa akan disertai kutipan dari penelitian-penelitian yang relevan.

e. Berdasarkan tinjauan pustaka, menuliskan best practices penerapan pembelajaran kooperatif dalam pembelajaran bahasa Inggris.

f. Membaca ulang, merevisi, dan mengedit draf modul. Setelah itu, modul akan dicetak kooperatif untuk meningkatkan kompetensi sikap peserta didik.

e. Menyelenggarakan pertemuan keempat dengan fokus pada peer teaching di mana tiga guru peserta pelatihan mendemonstrasikan penggunaan teknik-teknik pembelajaran kooperatif dalam pembelajaran bahasa Inggris SMP.

f. Menyelenggarakan pertemuan kelima dengan fokus pada rangkuman kegiatan, penguatan, dan pemberian balikan untuk tiga guru yang melaksanakan peer teaching dan dua guru yang mengikuti kegiatan pendampingan penerapan pembelajaran kooperatif.

Prosedur kerja untuk sub kegiatan terakhir, yaitu pendampingan penerapan pembelajaran kooperatif, langkahlangkahnya adalah sebagai berikut: 
a. Menawarkan kepada guru-guru MGMP mitra kesempatan untuk pendampingan dalam menerapkan pembelajaran kooperatif. Mempertimbangkan padatnya jadwal kegiatan pengabdian ini, tim pengabdi memberikan kesempatan tersebut hanya kepada dua orang guru. Pendampingan dilaksanakan di kelas bahasa Inggris dua guru tersebut di sekolah mereka masing-masing.

b. Menjadwal kegiatan pendampingan yang disusun dan disepakati bersama, yaitu oleh kedua guru, pengurus MGMP, dan tim pengabdi.

c. Memberikan balikan kepada ketiga guru dan menyampaikan hasil pendampingan (khususnya poin-poin yang telah disepakati oleh ketiga guru) kepada seluruh anggota MGMP saat penutupan kegiatan pengabdian kepada masyarakat ini.

\section{Partisipasi Mitra}

Partisipasi MGMP Bahasa Inggris SMP Sub Rayon 1 Ungaran sebagai mitra kegiatan pengabdian pada masyarakat ini adalah sebagai berikut:

a. Mengumumkan kegiatan pengabdian pada masyarakat ini kepada seluruh anggota dan melakukan koordinasi dengan mereka serta tim pengabdi selama kegiatan pengabdian berlangsung.

b. Menyampaikan kepada tim pengabdi teknik-teknik pembelajaran kooperatif yang telah dikuasai oleh sebagian besar anggota.

c. Menyediakan tempat pelatihan pembelajaran kooperatif.

d. Mengumunkan kepada seluruh anggota tentang peer teaching, mendorong partisipasi mereka, dan memberi dua nama guru yang bersedia melakukan peer teaching kepada tim pengabdi.

e. Membantu tim pengabdi dalam menuliskan rangkuman feedback (balikan) kepada dua guru yang telah selesai memperagakan penggunaan teknik pembelajaran kooperatif yang telah dipilih dalam peer teaching.

f. Mengumumkan kegiatan pendampingan penerapan pembelajaran kooperatif di sekolah kepada seluruh anggota.

g. Membantu tim pengabdi menyusun jadwal kegiatan pendampingan penerapan pembelajaran kooperatif.

h. Membantu tim pengabdi dalam menuliskan rangkuman feedback (balikan) untuk peserta pendampingan penerapan pembelajaran kooperatif di sekolah.

i. Membantu tim pengabdi dalam menyampaikan rangkuman feedback (balikan), baik dari kegiatan pelatihan (termasuk di dalamnya peer teaching) maupun pendampingan penerapan pembelajaran kooperatif, kepada seluruh anggota.

j. Membantu tim pengabdi mempersiapkan kegiatan penutupan.

k. Mendistribusikan modul pembelajaran kooperatif dan sertifikat kegiatan kepada seluruh anggota.

Seperti telah dikemukakan sebelumnya, kegiatan pengabdian pada masyarakat ini menghasilkan modul pembelajaran kooperatif untuk guru bahasa Inggris SMP. Berikut materi dalam modul tersebut:

Tabel 1 Materi dalam Modul

\begin{tabular}{cc}
\hline Bab & Isi \\
\hline 1 & Pendahuluan (definisi, prinsip-prinsip, dan teknik-teknik pembelajaran kooperatif) \\
\hline
\end{tabular}


2. Pembelajaran kooperatif untuk pengembangan kompetensi pengetahuan

3. Pembelajaran kooperatif untuk pengembangan kompetensi ketrampilan

4. Pembelajaran kooperatif untuk pengembangan kompetensi sikap

5. Penutup: From research to practice

\section{HASIL DAN PEMBAHASAN}

\section{Pelaksanaan Kegiatan}

Pada bagian ini akan digambarkan dan dipaparkan kegiatan pengabdian pada masyarakat yang telah dilaksanakan oleh tim pengabdi dan bagaimana setiap bagian/mata kegiatan membantu pencapaian tujuan yang telah ditentukan sebelumnya. Gambaran dan paparan ini ditulis berdasarkan urutan kegiatan/tanggal pelaksanaan sebagai berikut

\section{Pelatihan Pembelajaran Kooperatif untuk Pengembangan Kompetensi Pengetahuan Peserta Didik}

Kegiatan ini dilaksanakan pada hari Jumat tanggal 25 Agustus 2017 (pukul 13.00-15.00 WIB) dan bertempat di SMP 1 Ungaran yang dipilih oleh pengurus MGMP Bahasa Inggris Sub Rayon 1 Ungaran karena dianggap strategis atau mudah dijangkau oleh kebanyakan guruguru anggota. Pertemuan pertama ini dibuka oleh penanggung jawab MGMP Bahasa Inggris Sub Rayon 1 Ungaran, yaitu Ida Asroatul Mahmudah, M.Pd., dari SMP 4 Ungaran, dan diikuti oleh 24 guru (daftar hadir peserta setiap pertemuan dapat dilihat pada Lampiran 6).

Pelatihan dilaksanakan dalam format workshop, yaitu guru langsung mendapatkan pengalaman bagaimana pembelajaran kooperatif berlangsung. Dengan aktif, mereka berperan sebagai siswa-siswa SMP yang tengah belajar bahasa Inggris dan tim pengabdi berperan sebagai guru mereka (dokumentasi pertemuan pertama dapat dilihat pada Lampiran 7). Ada tiga teknik pembelajaran kooperatif yang menjadi fokus, yaitu: RoundRobin, Think Pair Share, dan Carousel Feedback. Materi lengkap untuk pertemuan pertama ini, termasuk prosedur ketiga teknik tersebut, terdapat di modul yang dibagikan kepada peserta pelatihan.

Yang menjadi catatan penting bagi tim pengabdi tentang pertemuan pertama ini adalah bahwa pengurus MGMP Bahasa Inggris Sub Rayon 1 Ungaran berinisiatif untuk mengundang guru-guru bahasa Inggris dari sub rayon lain untuk mengikuti kegiatan pengabdian pada masyarakat ini. Maksud mereka adalah agar kebermanfaatan kegiatan ini lebih luas.

Berikut ini adalah hasil refleksi beberapa guru peserta pertemuan pertama yang menunjukkan pemahaman mereka tentang bagaimana pembelajaran kooperatif dapat membantu meningkatkan kompetensi pengetahuan peserta didik, khususnya dalam pembelajaran bahasa Inggris:

a. Dalam Carousel Feedback siswa diharapkan memahani dengan materi yang diberikan guru yang pada akhirnya siswa dapat memberikan masukan/koreksi atas kesalahan yang dilakukan oleh teman-teman/kelompok lain. Masukan/koreksi tersebut akan membantu siswa lebih paham dengan materi tersebut.

b. Think Pair Share (TPS) dalam kelompok kecil maupun RoundRobin kemudian kunjungan karya dalam $\mathrm{KBM}$ /pembelajaran siswa, khususnya 
ketrampilan mendengarkan dan menulis, membuat siswa aktif, siswa produktif, saling bertanya jawab, memberikan komentar ke masingmasing kelompok sangat meningkatkan pengetahuan atau kompetensi siswa (pengetahuan/penguasaan

perbendaharaan kosakata terkair dengan lagu/materi yang disajikan).

c. Think Pair Share membantu siswa menggali pengetahuan mereka sendiri dan juga mengkonfirmasikannya dengan pengetahuan partner. Teknik ini juga membantu siswa mempresentasikan apa yang mereka ketahui sehingga menambah feedback untuk mereka.

d. RoundRobin membantu siswa berpikir mandiri dan sekaligus mengkomunikasikan pengetahuan mereka dalam kelompok. Secara otomatis siswa juga akan mendapatkan feedback dari anggota kelompok yang lain.

e. Menurut saya dengan teknik Think Pair Share siswa paling tidak mendapatkan pengetahuan/idea yang berbeda dengan teman lain meski hanya satu. Dan melalui RoundRobin siswa bisa menambah pengetahuan yang dia miliki dengan pengetahuan yang dia dapat dari teman-teman yang lain.

Berdasarkan refleksi di atas, dapat disimpulkan bahwa guru-guru peserta pelatihan telah memahami bahwa dalam pembelajaran kooperatif kompetensi pengetahuan peserta didik terbangun karena siswa saling berinteraksi satu sama lain, saling bertukar pemahaman dan/atau informasi, dan mendapatkan masukan dari rekan mereka. Hal ini selaras dengan hasil penelitian ketua tim pengabdi tentang peran pembelajaran kooperatif dalam pembelajaran bahasa Inggris, khususnya peran salah satu prinsipnya yaitu akuntabilitas individu (Astuti, 2016; Astuti \& Lammers, 2017a, 2017b).

\section{Pelatihan Pembelajaran Kooperatif Untuk Pengembangan Kompetensi Ketrampilan Peserta Didik}

Pertemuan kedua berlangsung pada hari Jumat, 8 September 2017, pukul 13.00-15.00 di SMP 1 Ungaran, dan dihadiri oleh 17 guru. Pada hari itu mereka mempelajari dua teknik pembelajaran kooperatif yaitu InsideOutside Circle dan One Stray. Seperti dalam pertemuan kedua, para guru mempelajari metode pembelajaran kooperatif melalui workshop. Seperti pada pertemuan pertama, guru-guru peserta pelatihan semangat mengikuti workshop seperti terlihat pada dokumentasi pertemuan kedua di Lampiran 8. Mereka mengalami dan mempelajari bagaimana kedua teknik pembelajaran kooperatif tersebut membangun keempat ketrampilan berbahasa Inggris: listening, speaking, reading, dan writing

Berikut ini catatan refleksi beberapa guru tentang bagaimana pembelajaran kooperatif dapat meningkatkan kompetensi ketrampilan berbahasa Inggris peserta didik:

a. Cooperative learninf type/technique Inside-Outside Cicle mampu mengembangkan ketrampilan mendengarkan [dan] berbicara siswa karena tiap siswa dalam tiap kelompok harus berkomunikasi dengan siswa [lain] secara berpasangan dan berputar sampai pasangannya habis/terakhir. Pembelajaran bahasa menggunakan type/technique ini, siswa aktif [dan] berani mengungkapkan pendapat/jawaban dari lawan/pasangannya. Siswa semakin percaya diri [dan] bisa berbicara/menjawab pertanyaan menggunakan bahasa Inggris dengan benar.

b. There are a lot of learning strategies whether speaking, listening, reading, or writing. One of them is Inside-Outside 
Cirlce. This strategy, that had been carried out for teaching spoken recount, significantly developed students' skills, especially in Students practice their listening on the first step comprehensively. Then they practice their ability in speaking. By doing it over and over again and changing their partner they increase their vocabulary and new idea.

c. Dengan Think Pair Share siswa dapat mengembangkan cara mengemukakan pendapatnya dengan lawan bicara siswa dapat mengeksporasi jawaban sebanyak mungkin informasi yang dia dapatkan.

d. Inside-Outside Circle membantu siswa menerapkan kemampuan menggali informasi melalui WH Questions setelah kemampuan listening terasah. Jadi kemampuan listening terintegrasi dengan kemampuan speaking dengan cara yang simple namun cukup membuat siswa aktif belajar dan berpikir.One Stray membantu siswa meningkatkan dua keterampilan yaitu writing dan reading. Yang pertama adalah writing, siswa dituntut untuk menuliskan ulang cerita yang sudah didengar dengan sudut pandang berbeda, kemudian reading dimana siswa membacakan hasil tulisannya (reading aloud). Disamping itu juga melatih penguasaan terhadap aspek membaca, misalnya pronunciation dan intonation.

Dapat disimpulkan dari tulisan (refleksi) di atas, dapat disimpulkan bahwa guru-guru peserta pelatihan memahami bahwa melalui pembelajaran kooperatif, empat keterampilan berbahasa Inggris peserta didik dapat terbangun karena mereka dituntut untuk presentasi/tampil dan berinteraksi dengan rekan sejawatnya, dan dalam aktifitasaktifitas ini mereka menggunakan paling tidak dua keterampilan berbahasa: listening-speaking atau reading-writing secara berulang-ulang.

Penelitian ketua tim pengabdi menunjukkan bahwa presentasi/tampil (performa) dan interaksi antar peserta didik dalam kelompok mereka adalah kegiatan-kegiatan yang menunjukkan/mendorong akuntabilitas individu, yang merupakan prinsip utama dalam pembelajaran kooperatif. Aktifitasaktifitas ini memainkan peran yang penting dalam membantu peserta didik/pembelajar bahasa Inggris mencapai kompetensi komunikatif (Astuti, 2016; Astuti \& Lammers, 2017a, Astuti \& Lammers, 2017b).

\section{Pelatihan Pembelajaran Kooperatif untuk Pengembangan Kompetensi Sikap Peserta Didik}

Pertemuan ketiga dengan tujuan membangun pemahaman dan memberikan pengalaman tentang bagaimana pembelajaran kooperatif meningkatkan kompetensi sikap berlangsung pada hari Jumat tanggal 15 September 2017 di SMP 1 Ungaran. Pertemuan ini diikuti oleh 17 guru. Teknik pembelajaran kooperatif yang mereka pelajari adalah Numbered Heads Together dan Talking Chips. Seperti dalam dua pertemuan sebelumnya, guru-guru peserta pelatihan mempelajari teknik-teknik pembelajaran tersebut melalui workshop. Mereka mendapatkan pengalaman menjadi peserta didik yang mempelajari bahasa Inggris dengan menggunakan dua teknik pembelajaran kooperatif tersebut dan berdiskusi tentang bagaimana kedia teknik pembelajaran kooperatif tersebut dapat membangun karakter-karakter berikut: jujur, disiplin, tanggung jawab, peduli (toleransi, gotong royong), santun, percaya diri. Karakterkarakter tersebut disebutkan dalam Standar Isi, Permendikbud nomor 21 tahun 2016, sebagai kompetensi sikap sosial yang perlu dibangun dalam diri siswa. Seperti pada pertemuan- pertemuan sebelumnya, guru-guru peserta aktif dalam mengikuti kegiatan pelatihan seperti terlihat dalam dokumentasi pada Lampiran 9. 
Berikut ini hasil refleksi beberapa guru peserta pelatihan, khususnya untuk pertemuan ketiga:

a.Numbered Heads Together can improve stu They have to be responsible with their an can improve students'confidenceselfand give a chance to their friends.

b.Numbered Heads Together dapat membangun kompetensi sikap peserta didik pada saat mereka harus mendengarkan pendapat anggota grup lain, yaitu mengajarkan sikap toleransi. Dan juga terbangun kerjasama karena mereka haris memutuskan jawaban melalui diskusi.

c.Talking Chips dapat membangun kompetensi sikap pada saat mereka harus memberi kesempatan orang lain untuk berbicara, juga membangun sikap kerjasama dengan membantu anak yang tidak punya ide untuk bicara. Di sini terbagun sikap tenggang rasa dan kerjasama.

d.By using Numbered Heads Together the students will learn how to respect others in discussion phase. In this phase, the students will give their ideas orally, and it will make them become a good listener because Respecting others is one of the social competencies that can be developed well by using this model.

e.Talking Chips dapat membangun sikap toleransi dan gotong royong. Sebagai contoh, sikap toleransi yang dikembangkan adalah: a) ketika bicara tidak rebutan, b) ada yang bicara harus diam, dan c) menghormati kemampuan orang lain. Sikap gotong royong terbangun contohnya saat tidak ada dominasi dalam suatu kelompok.

f. Menurut saya Numbered Heads Together mampu meningkatkan kompetensi sosial siswa. Ini dapat terlihat dari bagaimana siswa harus berbagi pendapat dan berdiskusi. Di sini siswa belajar untuk menghargai pendapat orang lain dan dapat bermusyawarah untuk menentukan jawaban yang benar. Serta ketika mereka menjawab pertanyaan apakah mereka melakukannya dengan percaya diri atau tidak. Siswa juga belajar untuk mengapresiasi penampilan siswa lain.

Dapat disimpulkan dari catatan refleksi di atas bahwa guru-guru peserta kegiatan pengabdian telah memahami bahwa melalui pembelajaran kooperatif, peserta didik mempraktekkan bahkan menjalankan karakter-karakter unggul yang diamanatkan oleh Standar Kompetensi. Menurut Kagan (2002), pengembangan karakter dengan metode ini lebih efektif karena peserta didik seperti "sekali merengkuh dayung, dua tiga pu mempelajari materi (mengembangkan kompetensi pengetahuan dan ketrampilan) tetapi juga menjalankan karakter-karakter unggul (mengembangkan kompetensi sikap) dalam kegiatan pembelajaran mereka.

\section{Pendampingan Pembelajaran Kooperatif}

Penerapan

Tim pengabdi menawarkan kepada guru-guru peserta pelatihan tentang kegiatan pendampingan penerapan pembelajaran kooperatif di kelas-kelas mereka dan mendapatkan dua (2) guru yang bersedia untuk mengikutinya, yaitu Hanjar Ani R. S. dari SMPN 1 Susukan dan Inayah Mala Hayati dari SMPN 3 Suruh. Kegiatan ini terlaksana pada hari Jumat tanggal 22 September 2017. Ketua tim pengabdi didampingi dua pengurus MGMP mengobservasi penerapan pembelajaran kooperatif dalam kegiatan pembelajaran di kelas kedua guru tersebut di sekolah masing-masing. Kepala sekolah mereka menyambut dengan baik kegiatan ini. Dokumentasi kegiatan ini dapat dilihat pada Lampiran 10.

$\mathrm{Bu}$ Hanjar menggunakan teknik Numbered Heads Together untuk 
mengajar procedure text (tentang cara membuat bola-bola coklat) di kelas IX, khususnya untuk melihat pemahaman siswa-siswanya tentang teks tersebut. $\mathrm{Bu}$ Inayah juga menggunakan teknik yang sama untuk mengajar tentang Family pada siswa-siswa kelas VII-nya. Berikut ini refleksi kedua guru tersebut tentang kegiatan pendampingan yang mereka ikuti.

Saya merasa takjub dengan sikap
anak-anak. Anak-anak sangat
antusias dalam menjawab
pertanyaan. Hal ini dapat terlihat
[dari] bagaimana cara mereka
menemukan jawaban, berbagi
pendapat dan mendiskusikan
jawaban dengan teman satu
kelompok. Saya merasa tidak
maksimal dalam melakukan
pembahasan teks procedure. Saya
akan mencoba menggunakan
Numbered Heads Together untuk
kompetensi listening. Hal ini
bertujuan untuk meningkatkan-
anak.Serta saya akan menambahkan
lembar kerja bagi anak-anak.
(Hanjar Ani R. S.)

Numbered Heads Together adalah salah satu model yang saya aplikasikan di kelas saya. Sangat menyenangkan bagi saya dan anakanak. Pertama kali memang anak masih bingung dengan apa yang harus mereka lakukan. Setelah menuju pertanyaan berikutnya mereka sangat terlibat di dalamnya. Tiap anak bekerja satu sama lain dalam satu kelompok. Berusaha untuk menjawab pertanyaan dengan baik dan benar. Pada fase berfikir anak sangat terlihat antusias. Pada saat fase mereka harus berdiskusi adalah fase yang sangat menarik karena tiap anak aktif di dalam kelompoknya masing-masing. Mereka mendiskusikan pertanyaan yang diberikan oleh guru dengan sangat antusias. Pada fase decide mereka memutuskan dengan sangat baik juga. Dan pada fase go sangat terlihat antusisme mereka untuk menjawab pertanyaan. I think that NHT can be applied well in 7 C. All of the phases ran well. But there was a group that wasn not as active as others. Saya sangat berharap kelima grup bisa sangat aktif, tapi ternyata amsh ada satu grup yang kurang aktif dalam pengaplikasian NHT di kelas 7 C. I will apply NHT for other classes and for listeninf like what sideswe'd doneI'll inpreparethetrainstud that it will imtpove the students' result. menggunakan model pembelajaran ini. Dengan saya menuliskannya dalam PTK saya yakin akan semakin banyak evaluasi dengan model ini sehingga saya akan mendapatkan salah satu midel pembelajaran yang dikombinasikan dengan media, lembar kerja, atau yang lain, sehingga hasil yang ingin dicapai bisa diraih dengan maksimal. (Inayah Mala Hayati)

Tulisan di atas menunjukkan bahwa kedua guru peserta kegiatan pendampingan merasakan manfaat penerapan teknik Numbered Heads Together dalam pengajaran mereka, terutama untuk meningkatkan keantusiasan dan keaktifan siswa-siswa mereka dalam mengikuti pembelajaran. Mereka juga berencana untuk menggunakan teknik tersebut untuk mengajar ketrampilan listening atau menyimak. Di samping itu, kedua guru peserta kegiatan pendampingan mempunyai catatan mereka untuk perbaikan penerapan Numbered Heads Together di pengajaran mereka berikutnya.

\section{Peer Teaching/ Mengajar Rekan Sejawat dengan Menggunakan Pembelajaran Kooperatif}

Agenda pertemuan keempat dengan guru-guru peserta pelatihan adalah peer teaching di mana tiga dari mereka memperagakan pembelajaran kooperatif dalam mengajar rekan sejawat mereka. Tiga guru tersebut adalah: Jadi Mulyono 
(SMP Issud Ambarawa), Endah Puji L. (SMPN 1 Susukan), dan Peni Sri Rejeki (SMP Assalamah Ungaran). Pengurus MGMP membantu tim pengabdi untuk memilih dan/atau mendapatkan ketiga guru tersebut. Kegiatan ini dilaksanakan pada hari Jumat tanggal 6 Oktober 2017 bertempat di SMPN 1 Ungaran dan diikuti oleh 18 guru. Setiap guru peer teaching mendapatkan waktu kurang lebih 20 menit untuk peragaan mereka.

Pak Jadi memperagakan penggunaan teknik Send a Problem untuk mengajar descriptive text. Teknik ini tidak diajarkan selama pelatihan dan menunjukan bahwa pembelajaran kooperatif telah dikenal dan/atau telah diterapkan oleh sebagian guru-guru peserta pelatihan dalam pengajaran mereka. Bu Endah menerapkan teknik Inside-Outside Circle untuk mengajarkan how to tell dates and months sementara $\mathrm{Bu}$ Peni menerapkan Think Pair Share dan Carrousel Feedback untuk mengajar tentang occupations. Teknik-teknik yang digunakan oleh $\mathrm{Bu}$ Endah dan $\mathrm{Bu}$ Peni dipelajari saat pelatihan. Ketiga guru tersebut dan rekan-rekan sejawat peserta pelatihan mengikuti kegiatan peer teaching dengan aktif seperti terlihat pada dokumentasi kegiatan ini pada Lampiran 11 .

\section{Kegaiatan Penutup}

Pertemuan terakhir dalam rangkaian kegiatan pengabdian dilaksanakan pada hari Jumat tanggal 13 Oktober 2017 di SMPN 1 Ungaran, yang diikuti oleh 19 guru. Kegiatan diawali dengan mengulas, membahas kembali, dan memberikan penguatan tentang apa yang telah dipelajari pada pertemuan-pertemuan sebelumnya, termasuk kegiatan pendampingan penerapan pembelajaran kooperatif. Tim pengabdi mengajak peserta untuk flashback kegiatan dan materi peer teaching pada pertemuan keempat, sharing hasil kegiatan pendampingan, dan fashback kegiatan dan materi pelatihan pembelajaran kooperatif untuk pengembangan kompetensi pengetahuan (pertemuan pertama), ketrampilan (pertemuan kedua), dan sikap (pertemuan ketiga). Dokumentasi kegiatan penutup ini dapat pada Lampiran 12.

Untuk ketiga guru penampil peer teaching tim pengabdi memberikan masukan bahwa pada saat peserta didik bekerja dalam kelompok guru harus memonitor bahwa setiap anggota kelompok memberikan kontribusi pada pembelajaran yang tengah berlangsung dalam kelompok mereka masing-masing. Oleh karena itu, guru perlu memberikan cukup waktu agar peserta didik dapat melakukannya, yaitu dengan mempelajari materi pembelajaran yang tengah menjadi target.

Bersama dua pengurus MGMP yaitu Ibu M. Rustini dan Ibu Tri Astuti Ari Winarni, tim pengabdi kemudian menyampaikan hasil kegiatan pendampingan penerapan pembelajaran kooperatif diantaranya yaitu: a) peserta didik antusias dan aktif dalam mengikuti kegiatan pembelajaran, b) kedua guru peserta pendampingan tidak menyangka bahwa penggunaan teknik pembelajaran kooperatif di kelasnya mendapat sambutan yang sangat baik dari siswa-siswa mereka, c) bahwa langkah-langkah teknik Numbered Heads Together membantu guru untuk menyeimbangkan antara learning ( $\mathrm{di}$ mana siswa mempelajari materi yang menjadi target) dan performing (di mana siswa menyampaikan apa yang telah dipelajari dan berinteraksi dengan rekan sejawat mereka untuk saling memberikan masukan).

Flashback kegiatan dan materi pelatihan pembelajaran kooperatif untuk pengembangan kompetensi pengetahuan (pertemuan pertama), ketrampilan (pertemuan kedua), dan sikap (pertemuan 
ketiga) dilakukan dengan tanya jawab dan pemberian penguatan (reinforcement) yang mencakup hal-hal sebagai berikut: a) bahwa peserta didik membangun pemahaman tentang materi yang menjadi target melalui fase learning (dalam hal ini mereka mengembangkan kompetensi pengetahuan), b) bahwa peserta didik membangun keterampilan berbahasa yang menjadi target melalui fase performing (dalam hal ini mereka mengembangkan kompetensi ketrampilan), c) bahwa peserta didik menjalankan karakterkarakter yang diamanatkan Standar Proses dalam mengikuti kegiatan pembelajaran (dalam hal ini mereka mengembangkan kompetensi sikap), d) bahwa fase learning dan performing berlangsung ketika peserta didik belajar melalui pembelajaran kooperatif, e) bahwa learning dan performing adalah aktifitas-aktifitas yang menunjukkan dan/atau mendorong individual accountability (akuntabilitas individu) yang merupakan prinsip utama dalam pembelajaran kooperatif, dan f) bahwa aktifitas-aktifitas akuntabilitas individu tersebut dapat membantu peserta didik untuk mencapai kompetensi komunikatif dalam bahasa Inggris.

Pertemuan kelima atau terakhir ini kemudian ditutup oleh penanggung jawab MGMP Bahasa Inggris Sub Rayon 1 Ungaran, Ibu Ida Asroatul Mahmudah, M.Pd., yang menyatakan harapannya agar kegiatan serupa dapat dilaksanakan kembali dan agar guru-guru peserta pelatihan dapat menerapkan apa yang telah dipelajari agar pembelajaran di kelas-kelas mereka berlangsung efektif. Pengurus MGMP juga menyampaikan rencana untuk menuangkan pengalaman guru-guru peserta pelatihan dalam menerapkan pembelajaran kooperatif dalam sebuah buku. Dalam prosesnya nanti, mereka meminta tim pengabdi untuk terlibat terutama untuk bagian yang berhubungan dengan teori pembelajaran kooperatif.

\section{SIMPULAN}

Seluruh rangkain kegiatan pengabdian pada masyarakat, yaitu: penyusunan modul, pelatihan penerapan pembelajaran kooperatif untuk pengembangan kompetensi pengetahuan, ketrampilan, sikap peserta didik, pendampingan penerapan pembelajaran kooperatif, dan peer teaching telah selesai dilaksanakan. Setiap kegiatan berlangsung dengan lancar dan mendapat sambutan yang bagus dari pengurus MGMP dan guru-guru peserta pelatihan. Pengetahuan, ketrampilan, dan pengalaman mereka dalam menerapkan pembelajaran kooperatif dalam lingkup Kurtilas terbangun melalui kegiatan pengabdian ini seperti terlihat dari tulisan/refleksi mereka, performa mereka dalam kegiatan pendampingan dan peer teaching, dan dalam perbincangan informal dengan mereka selama kegiatan pengabdian berlangsung. Tidak kalah pentingnya untuk dijadikan catatan tim pengabdi adalah rencana mereka untuk menuangkan pengalaman mereka dalam menerapkan pembelajaran kooperatif, yang menunjukkan terbangunnya efficacy mereka, yaitu keyakinan bahwa mereka mampu menerapkan metode pembelajaran ini dalam menyelenggarakan kegiatan pembelajaran di kelas-kelas mereka.

\section{DAFTAR PUSTAKA}

Ahmad, D. (2016). Exploring policymakers`and English teachers` perceptions and interpretations in Makassar towards Curriculum 2013 (A mixed-design study). (Paper presented at Indonesia TESOL Conference 2016). Retrieved from http://tesol.id/2016conference/2016/07/28/ exploring policymakers-andenglish- teachers-perceptions-and- 
interpretations-in-makassartowards-curriculum-2013-a-mixeddesign-study/

Albana, H.H. (2016). English teachers' persp A case study at seventh class of SMPN 3 South Tangerang in academic year 2015/2016. (Final Project. Universitas Islam Negeri Sharif Hidayatullah Jakarta)

Astuti, P. (2016). "I can teach them; they can teach me": cooperative learning in Indonesian secondary school EFL classrooms. (Doctoral Dissertation. University of Rochester, New York, USA).

Astuti, P., \& Lammers, J. C. (2017a). Individual Accountability in Cooperative Learning: More opportunities to produce spoken English. Indonesian Journal of Applied Linguistics, 7(1), 215-228.

Astuti, P., \& Lammers, J. C. (2017b). Making EFL Instruction More CltOriented through Individual Accountability in Cooperative Learning. TEFLIN Journal, 28(2), 236-259.

Badan Standar Nasional Pendidikan.2016. Peraturan Menteri Pendidikan dan Kebudayaan Nomor 22 Tahun 2016 tentang Standar Proses Pendidikan Dasar dan Menengah.Jakarta: BNSP.

Badan Standar Nasional Pendidikan.2016. Peraturan Menteri Pendidikan dan Kebudayaan Nomor 21 Tahun 2016 tentang Standar Isi Pendidikan Dasar dan Menengah. Jakarta: BNSP.

Bejarano, Y. (1987). A cooperative smallgroup methodology in the language classroom.TESOL Quarterly, 21, 483-504.

Coelho, E. (2009). Cooperative learning: foundation for a communicative curriculum. In Kessler, C. (Ed.), Cooperative language learning (pp.
31-49). Upper Saddle River, NJ: Prentice-Hall, Inc.

Cohen, E. G. (1994).Restructuring the classroom: Conditions for productive small groups.Review of Educational Research, 64(1), 1-35. DOI: 10.3102/00346543064001001

Chen, H. (2011). Structuring cooperative learning in teaching English pronunciation.English Language Teaching, 4(3), 26-32.

Ghaith, G. (2003). Effects of the learning together model of cooperative learning on English as a foreign language reading achievement, academic self-esteem, and feelings of school alienation.Bilingual Research Journal, 27, 451-474.

Hijazi, D. \& Al-Natour, A. (2012)towards. usingTeachers'CLforteachingEnglis hattitudes skills. Interdisciplinary Journal of Contemporary Research in Business, 3, 443-460.

Johnson, D. W. \& Johnson, R. T. (1999). Making cooperative learning work. Theory into Practice, 38(2), 67-73.

Keyser, M. W. (2000). Active learning and cooperative learning: understanding the difference and using both styles effectively. Research Strategies, 17(1), 35-44.

Kagan, Spencer. 2002. The Structural Approach to Character Development. Available at http://www.cooperativelearning.com /KaganClub/FreeArticles. html. Accessed on April 1, 2010.

Kagan, S., \& Kagan, M. (2009).Kagan cooperative learning.San Clemente, CA: Kagan Publishing.

Liang, T. (2002).Implementing cooperative learning in EFL teaching: Process and effects (Unpublished master's thesis).National Tai

Larsen-Freeman, D. (2012). From unity to diversity: twenty-five years of 
language-teaching methodology. English Teaching Forum, 50(2), 28-38.

Richards, J. C. (2002). 30 Years of TEFL/TESL: A personal reflection. RELC Journal, 33(1), 1-35.

Sharan, S. (2002).Differentiating methods of cooperative learning in research and practice.Asia Pacific Journal of Education, 22(1), 106-116.

Slavin, R. E. (1980).Cooperative learning.Review of Educational Research Summer, 50, 315-342.

Slavin, R. E. (1990).Cooperative learning: Theory, research, and practice. Boston, MA: Allyn and Bacon.

Syafini \& Rizan, N. (2009). The effects of cooperative learning in enhancing writing performance. Proceedings retrieved from http://www.ukm.my/solls09/Proce eding/PDF/Shafini.pdf

Sachs, G. T., Candlin, C. N., \& Rose, K. R. (2003).Developing cooperative learning in the EFL/ESL secondary classroom.RELC Journal, 34, 338-369.

Sundayana, W. (2015).Readiness and competence of senior high school English teachers to implement curriculum 2013.Indonesian Journal of Applied Linguistics, 51(1), 29-36. 
244

Rekayasa Vol. 16 No.2, Desember 2018 